\title{
NISTIR 6077
}

\section{THE U.S. CERTIFICATION SYSTEM FROM A GOVERNMENTAL PERSPECTIVE}

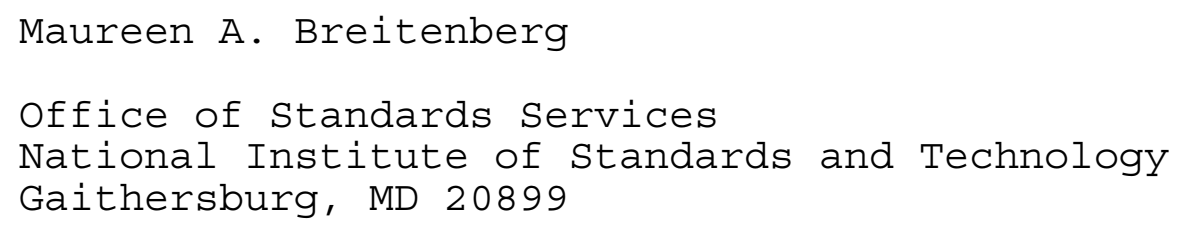




\section{Foreword}

The Office of Standards Services periodically publishes information related to certification as a service to producers and users of such systems -- both in the government and in the private sector. This report provides those not fully familiar with this field with an introduction to some of its complexities from a governmental perspective. We hope that this material will be informative and will serve to stimulate wider understanding of the purpose and nature of the government's involvement in certification programs.

The interested reader may wish to take advantage of other available publications and services provided by the Office of standards Services. 


\section{Acknowledgements}

I would like to thank Charles Hyer, The Marley Organization; Patrick Cooke, Walter Leight, and Mary Saunders, NIST; and many others for their careful review of and comments on this document.

Maureen A. Breitenberg

Office of Standards Services 


\section{Abstract}

This report is designed to provide the reader with an introduction to the U.S. certification system from a governmental perspective. It highlights some of the relationships that exist between federal and state agencies and the private sector and discusses some of the history and philosophy behind the U.S. system.

Key Words: certificates of conformity; certification; certification marks; conformity assessment; product approval; standardization; standards; testing 


\section{Table of Contents}

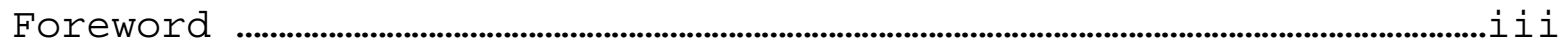

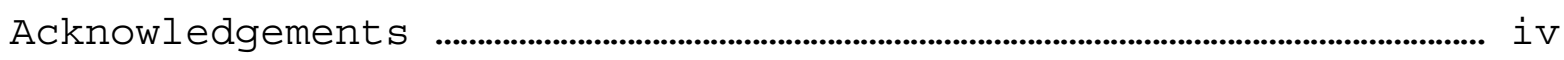

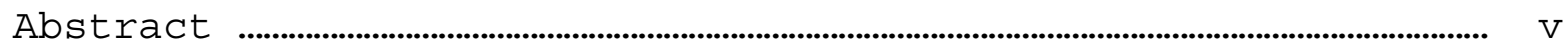

Introduction

U.S. Regulatory Philosophy ......................................................................................... 2

False and Misleading Advertising Prohibitions ...................................... 3

Industry Self-Policing Efforts ........................................................................... 3

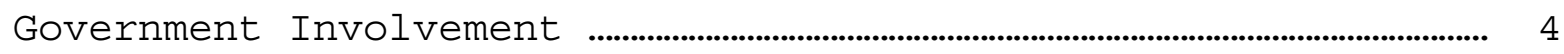

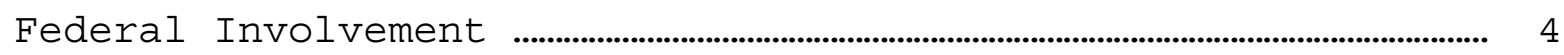

Federal Involvement in Certification Program Accreditation... 6

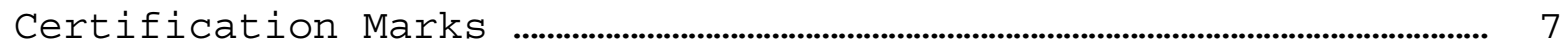

State/Local Government Involvement ...................................................................... 10

Transparency in the Development of U.S. Regulations ..................... 11

Other U.S. Statutory and Legal Obligations in the Certification

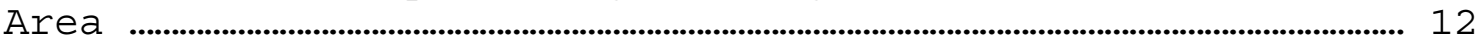

Conclusion 


\section{INTRODUCTION}

After declaring independence from England and prior to the formation of the United States of America, authority to regulate products and to conduct such product assessments as were deemed necessary rested with the individual states. With the signing of the U.S.

Constitution, states gave to the federal government the authority to "regulate Commerce with foreign Nations, and among the several States, and with the Indian tribes..." However, in the first ten amendments to the Constitution, also known as the "Bill of Rights," the States spelled out that the ". powers not delegated to the United States by the Constitution, nor prohibited by it to the states, are reserved to the states respectively, or to the people." As a result, authority in the United States to regulate products (and to assess the conformity of products to mandatory requirements) is split between the federal and state governments.

Conformity assessment is defined in ISO/IEC ${ }^{1}$ Guide 2: 1996 as: "any activity concerned with determining directly or indirectly that relevant requirements are fulfilled." Conformity assessment procedures provide a means of ensuring that the products, services, or systems produced or operated have the required characteristics, and that these characteristics are consistent from product to product, service to service, or system to system. Conformity assessment includes: sampling and testing; inspection;

certification (of both products and personnel); and quality and environmental system assessment and registration. ${ }^{3}$ Conformity assessment also includes accreditation of the competence of those activities by a third party and recognition (usually by a

ISO is the acronym for the International Organization for Standardization, while IEC stands for the International

Electrotechnical commission. The International Organization for Standardization (ISO) is a worldwide federation of over 90 national standards bodies. ISO covers standardization in all fields, except the electrical and electronics fields which are covered by the International Electrotechnical Commission (IEC). IEC has members from over 40 countries which represent some $80 \%$ of the world's population. Together ISO and IEC form the world's largest nongovernmental system for voluntary industrial and technical collaboration in the field of standardization.

2 Some organizations use other terms to refer to the process, such as product listing, product evaluation, product regulation, product approval, or the publication of research reports, but in this

discussion, we will use the term "certification." The reader should be aware of the existence and use of other terms, however, to describe this activity.

3 In Europe, quality and environmental system registration is often referred to as certification. 

government agency) of an accreditation program's capability.

It should be recognized that product certification, the type of conformity assessment discussed in this paper, is only one type of conformity assessment.

At the federal level, one of the first instances of major regulatory involvement in product certification occurred approximately 60 years ago. At that time U.S. drug manufacturers could produce and sell drugs without testing them on either animals or humans and without any kind of governmental approval. Governmental action could be taken only against drugs which were misbranded or adulterated. In 1937, physicians in Tulsa, Oklahoma reported to the American Medical Association (AMA) the deaths of six patients from a liquified version of the then wonder drug sulfa. This drug ultimately killed 107 people, mostly children, before doctors realized what was happening and the drug was recalled. This tragedy led to the enactment of the 1938 Food, Drug and Cosmetic Act, which requires that drugs be tested and approved by the Food and Drug Administration (FDA) before marketing. From such early beginnings, the federal involvement in certification has grown both in extent and complexity.

\section{U.S. REGULATORY PHILOSOPHY}

It might be useful to know something about the United states' regulatory philosophy to understand when federal or state government agencies are likely to become involved in conformity assessment, especially product certification. The United States's regulatory philosophy relies heavily on a manufacturer's declaration of conformity (or self-certification) wherever possible. Manufacturers' declaration of conformity is one of the oldest and simplest forms of certification. The vast majority of U.S. marketplace transactions involve only the buyer and the seller -without intervention by any third party, whether government or the private sector.

There are a number of reasons why this approach is successful in the United States. These include: (1) the sometimes severe penalties imposed by the U.S. legal and judicial system on products proven to be defective or hazardous to the public safety or environment; (2) the increasing access that the U.S. consumer has to information about poor quality or hazardous and defective products through various news and publications media; (3) the size of the U.S. marketplace and the ability of the U.S. consumer to switch to a competing product if dissatisfied; and (4) U.S. laws and regulations regarding truth in labeling and advertising. 
The last three serve to increase consumer protection by enabling U.S. consumers to make better informed decisions regarding the products they purchase and to switch to brands if dissatisfied. 


\section{FALSE AND MISLEADING ADVERTISING PROHIBITIONS}

As noted above, one reason why the U.S. system works is that there are a number of federal and state laws and regulations ${ }^{4}$ that prohibit the use of false or misleading labeling or advertising of products or services sold in the United States. In some cases, U.S. laws and regulations not only prohibit false or misleading labeling or advertising, but also mandate that information regarding certain characteristics of a product or service be disclosed to buyers. At the federal level, one of most important laws in this area, which is enforced by the Federal Trade Commission (FTC), is The Fair Packaging and Labeling Act. This Act requires consumer commodities to be accurately labeled regarding the description of the product's identity and net quantity. The Textile, Wool, and Fur Acts, also enforced by the FTC, protect consumers against misleading or false advertising and invoicing of textile, wool, and fur products. On the other hand, the Appliance Labeling Rule, a joint FTC/U.S. Department of Energy (DOE) regulation, is an example of a regulation that requires the disclosure of information to buyers, namely specific information on the energy costs or efficiencies of major home appliances.

While the FTC is not authorized to resolve individual consumer complaints (though most states have established offices for this purpose), letters from consumers can trigger investigations of an industry or of a specific company. If, during an investigation, the FTC staff find reason to believe that a company has violated the law, and if the case is not settled by a formal agreement with the company (a consent order), the Commission can decide to sue the company. Depending on circumstances, the case may be tried before an administrative law judge or in federal court. The FTC may seek a cease and desist order, a preliminary or permanent injunction against the sale of the product, consumer redress, or other appropriate relief.

\section{INDUSTRY SELF-POLICING EFFORTS}

When a manufacturer's declaration of conformity combined with federal and state prohibitions on the use of false or misleading labeling or advertising, does not afford sufficient marketplace protection, the government will frequently rely on self-policing efforts by the affected industry. A number of private sector industry or trade associations conduct conformity assessment programs, especially product certification programs, to:

These laws are enforced by the U.S. Federal Trade Commission (FTC) at the national level and by most states through the offices of the state's Attorney General. 
(1) enhance the reputation of their industry;

(2) provide manufacturers with some assurance regarding product quality, safety, environmental impact, or compliance with mandatory requirements;

(3) level the playing field, that is, establish a minimum level of quality or safety for products produced by their industry and provide consumers with a means to identify products which meet those minimum requirements; and

(4) avoid the need for government regulation.

\section{GOVERNMENT INVOLVEMENT}

Although the U.S. Government relies to a large extent on manufacturers' declarations of conformity to both mandatory and voluntary product requirements, as well as on industry's self-policing efforts, if a product fails to meet mandatory requirements, the federal agency with jurisdiction over that product has the authority to take enforcement action against the producer, supplier or distributor of the product. Governmental reliance on a manufacturer's or supplier's declaration of conformity does not preclude the federal government from taking whatever action it deems necessary against a manufacturer or supplier if the government determines that a product is not in compliance with regulatory requirements.

In addition, when manufacturer's self-declarations or industry self-policing efforts are not effective or adequate, government agencies may become more directly involved in the assessment of compliance with mandatory product requirements. If the problem with a specific product or service is a local one, states and local government agencies are likely to be the responsible authorities. If a serious problem exists, which is national in scope and which cannot be adequately or economically addressed at the state and local levels, then the federal government is likely to get involved.

\section{FEDERAL INVOLVEMENT}

Federal government involvement generally occurs when Congress passes a law giving a specific federal agency the statutory authority required to address such a problem at the national level. Federal agencies then develop regulations to implement that law. As required 
by the Administrative Procedure Act, such regulations go through an extensive public review and comment process before they become final - a process discussed in more detail later.

In addition to regulatory programs, federal agencies also conduct a number of other types of certification programs. In general, federal government certification programs can be classified into several general categories:

- Programs to certify products which directly affect the health or safety of the user or the general public.

- Programs to test products to avoid the necessity for retesting at local levels or prior to each procurement.

- Programs to provide a uniform basis for trade by assessing the quality and condition of products offered for sale.

Examples of the first type of certification program include the evaluation and approval by the Food and Drug Administration (FDA), U.S. Department of Health and Human Services, of new animal and human drugs, medical devices, biologicals, and other products; the certification by the Federal Aviation Administration (FAA), U.S. Department of Transportation, of airplanes and major airplane components; respirators and other breathing apparatus by the National Institute for Occupational Safety and Health; and the certification by the Mine Safety and Health Administration (MSHA), Department of Labor, of electrical and other potentially hazardous equipment used in mines.

An example of the second type of program is the Department of Defense's (DOD) Qualified Products Listing (QPL) Program for parts, materials and components used in military systems. This program reduces retesting prior to each government purchase by testing products and placing those approved on appropriate QPL's. An extension of this concept also underlies the DOD Qualified Manufacturing Lists (QML's) Program, in which a manufacturer's process controls and manufacturing capabilities are evaluated and approved for an entire range of products.

An example of the third type of program is the U.S. Department of Agriculture's (USDA) program to grade and certify meat and meat products (on a voluntary basis) using uniform grading standards for the buying and selling of such products. The USDA also certifies dairy products, fresh and processed fruits, vegetables, nuts and related products. The National Oceanic and Atmospheric Administration (NOAA), U.S. Department of Commerce, likewise inspects and grades processed fish and shellfish at a seafood processor's request. 
The complexity of such programs and the procedures used by each can vary extensively depending on purpose, the nature of the product or service, as well as the extent to which private sector programs are available and effective and can be used to supplement federal efforts. More complex and comprehensive programs tend to be more effective, but they also tend to be more costly. The federal government is obligated (by law in the regulatory area) to consider both

effectiveness and cost and to weigh the two when establishing a new program.

\section{FEDERAL GOVERNMENT INVOLVEMENT IN CERTIFICATION PROGRAM ACCREDITATION}

The U.S. accreditation system for certification programs is less complex than other U.S. conformity assessment areas, primarily because the United States only has a few major programs. The most prominent government program of this type is operated by Occupational Safety and Health Administration (OSHA) within the U.S. Department of Labor (DOL).

OSHA's program covers electrical equipment/materials used in the work place. By law, all electrical products used in the work place must be tested and listed or labelled by a certifier (known as a Nationally Recognized Testing Laboratory, or NRTL) which is recognized/approved by OSHA. NRTLs are private sector certifiers, and participation in the OSHA program is voluntary. However, if certifiers wish to test such products, they must be recognized/approved by OSHA. ${ }^{5}$ NRTLs are subject to review at least once every 5 years. Applicants for OSHA recognition as an NRTL must have adequate administrative and technical capability to be able to certify products in the areas for which they seek approval/recognition. They must also be able to inspect factory production runs as part of a product's evaluation and to conduct field inspections to ensure proper use of the certifier's identifying mark or label on the product. The program is open to all U.S. certifiers and to foreign certifiers if the countries of those foreign certifiers are open to U.S. certifiers.

The National Institute of Standards and Technology can also accredit certifiers under its National Voluntary Conformity Assessment Evaluation (NVCASE) Program. The program is intended to enable the Department of Commerce, acting through NIST, to evaluate and recognize competently conducted U.S. conformity assessment activities, including certification, which are capable of meeting regulatory requirements of another country with which the United

\footnotetext{
5 OSHA is responsible for the regulation of all electrical products used in the work place. For a list of the products under OSHA's jurisdiction which require certification by a Nationally Recognized Testing Laboratory (NRTL), see 29 CFR 1910.
} 
States has an applicable mutual recognition agreement. The program supplements the programs of other federal agencies and is generally initiated upon NIST's receipt of a request for assistance from the appropriate U.S. regulatory agency. The results of NIST evaluations provide a basis for the U.S. Government to assure foreign governments that qualified U.S. conformity assessment bodies are competent and can satisfy foreign regulatory requirements. NIST will conduct evaluations using publicly developed requirements based to the maximum extent possible on international guides and standards for the acceptance of conformity assessment activities. The program operates on a fee-for-service basis. NIST provides a certificate of recognition to a body meeting the requirements and maintain lists of all qualified conformity assessment bodies.

\section{CERTIFICATION MARKS}

The federal government is also concerned with the registration of marks used in certification programs due to the increasing international use and importance of these marks in the marketplace.

One of the most interesting things NIST learned during the latest revision of NIST SP 774, the Directory of Private Sector Product Certification Programs, was that while many, but not all, of the marks used in certification programs are registered with the U.S. Patent and Trademark Office (PTO), many of these registered marks are not "certification marks" as defined by U.S. law.

To explain this situation, it may be helpful to quote selectively from the definitions for the various types of registered marks and related definitions contained in Section 1127, "Construction and

Definitions," of the Trademark Act of 1946 ("Lanham Act") as amended.

"The term 'person' and any other word used to designate the applicant or other entitled to a benefit or privilege or rendered liable under the provisions of this Act ... includes a juristic person as well as a natural person. The term 'juristic person' includes a firm, corporation, union, association, or other organization capable of suing and being sued in a court of law."

"The term 'person' ... includes any state, instrumentality of a State and any officer or employee of a state or instrumentality of a state acting in his or her official capacity. Any state, and any such instrumentality, officer or employee, shall be subject to the provisions of this Act in the same manner and to the same extent as any nongovernmental entity." 
"The terms 'applicant' and 'registrant' embrace the legal representatives, predecessors, successors and assigns of such applicant or registrant."

"The term 'related company' means any person whose use of a mark is controlled by the owner of the mark with respect to the nature and quality of the goods and services on or in connection with which the mark is used."

"The terms 'trade name' and 'commercial name' mean any name used by a person to identify his or her business or vocation."

"The term 'trademark' includes any word, name, symbol, or device or any combination thereof --

(1) used by a person; or

(2) which a person has a bona fide intention to use in commerce and applies to register on the principal register established by this Act,

to identify and distinguish his or her goods, including a unique product, from those manufactured or sold by others and to indicate the source of goods, even if that source is unknown."

"The term 'service mark' means any word, name, symbol, or device or any combination thereof --

(1) used by a person, or

(2) which a person has a bona fide intention to use in commerce and applies to register on the principal register established by this Act,

to identify and distinguish the services of one person, including a unique service, from the services of others and to indicate the source of the services, even if that source is unknown. Titles, character names, and other distinctive features of radio or television programs may be registered as service marks notwithstanding that they, or the programs, may advertise the goods of the sponsor."

"The term 'certification mark' means any word, name, symbol, or device or any combination thereof --

(1) used by a person other than its owner, or

(2) which its owner has a bona fide intention to permit a person other than the owner to use in commerce and files an application to register on the principal register established by this Act, to certify regional or other origin, material, mode of manufacture, quality, accuracy, or other characteristics of such person's goods or services or that the work or labor on the goods or services was performed by members of a union or other organization." 
"The term 'collective mark' means a trademark or service mark -(1) used by members of a cooperative, an association or other collective group or organization, or

(2) which such cooperative, association, or other collective group or organization has a bona fide intention to use in commerce and applies to register on the principal register established by this Act,

and includes marks indicating membership in a union, an association or other organization."

"The term 'used in commerce' means the bona fide use of a mark in the ordinary course of trade, and not made merely to reserve a right in a mark."

"The term 'mark' includes any trademark, service mark, collective mark, or certification mark."

U.S. certification programs use ALL of these types of registration marks defined in the Trademark Act. In fact, only a few programs use federally-registered certification marks as defined by the Trademark Act. In addition, unregistered marks (often

initializations/acronyms and/or symbols/logos used on letterheads and reports to identify the organizations that provide product certification) are also used in U.S. certification programs. The type of mark used by a particular program is based on the type of organization which runs the program (e.g., an independent laboratory or a trade association); existing ownership of a well recognized trademark, service mark, or collective mark; familiarity on the part of the certifier with the different categories of marks; and the cost and perceived need for a registered mark.

In drafting certification-related regulations, several government agencies have already learned that the terminology used in connection with marking requirements can have a major impact on the number and types of organizations eligible to participate in the conformity assessment program. For example, requiring certification programs to have a certification mark (as distinct from some other type of mark) can eliminate many U.S. certification programs from participation.

Some agencies also own certification marks which are registered with the U.S. Patent and Trademark Office and which are used in their product approval/certification programs. Examples include the Department of Transportation mark in its program for tanks used in the transport of hazardous materials. The U.S. Department of Agriculture owns and uses several marks in connection with its poultry and meat grading programs, and the Environmental Protection Agency uses its Energy star mark in programs designed to promote the manufacture and use of more energy efficient products. 


\section{STATE/LOCAL GOVERNMENT INVOLVEMENT}

As noted above, federal agencies are not the only U.S. governmental agencies with authority regarding certification. States administer many different types of certification programs covering a diversity of products. In some cases, states inspect or test products under authority delegated by the federal government. For example, many states inspect meat and meat products, certifying those that meet standards established by the USDA. These states then authorize the use of the appropriate USDA marks. Many states also inspect and issue certificates of conformity for manufactured homes under authority delegated by the U.S. Department of Housing and Urban Development (HUD). Most state and local jurisdictions also have responsibility for water quality testing under authority delegated to them by the U.S. Environmental Protection Agency (EPA). States may also impose additional state requirements and simultaneously check for conformity to both state and federal requirements.

States regulate products under their own authority for health and safety reasons, including amusement rides and thermal insulation, depending on each state's perception of the health and safety impact of such products on its population. Products may be inspected and/or tested directly by the states themselves, or indirectly through a requirement that such products be inspected and/or tested and certified by an approved body, such as a nationally recognized laboratory. An example of the latter is the regulation of electrical building products by imposing a state requirement that they be tested/inspected and bear the mark of a "nationally recognized testing laboratory." The term "nationally recognized laboratory" is currently defined by each state and/or municipality.

States regulate products of direct or indirect economic importance. Florida and California, for example, inspect products important to their citrus fruit industry. Nebraska, with a considerable agricultural industry, regulates tractors through a testing program at the University of Nebraska and issues certificates of conformity for approved models. California, with its air pollution problem, stringently regulates auto emissions equipment.

States inspect, test, and/or certify materials, products, systems and services they procure, such as materials for the construction of state roads and bridges. In yet other cases, the states establish standards, but leave enforcement (testing, inspection, etc.) to local authorities. This is sometimes true for building and construction materials. 
Again, the complexity of such state and local programs and the procedures used can differ greatly just as they can at the federal level, depending on the purpose of the program, the nature of the product or service, and the extent to which private sector programs are available and effective.

\section{TRANSPARENCY IN THE DEVELOPMENT OF U.S. REGULATIONS}

As mentioned earlier in this paper, the federal government develops regulations, including those with conformity assessment requirements, only after an extensive public review and comment process. The Administrative Procedure Act (APA) establishes general procedures for rulemaking which must be followed by U.S. federal government agencies (5 U.S.C. section 551 et seq.). At a minimum, the APA requires that for the issuance of a substantive rule (as distinguished from a procedural rule or statement of policy), an agency must:

(1) Publish a notice of proposed rulemaking in the Federal Register. This notice must set forth the text or the substance of the proposed rule, the legal authority for the rulemaking proceeding, and applicable times and places for public participation.

(2) Provide all interested parties - - national and non-national alike -- an adequate opportunity for submission of written comments on the proposed rule. This public comment process serves a number of purposes, including giving interested persons the opportunity to provide the agency with information that will enhance the agency's knowledge of the subject matter of the rulemaking. The public comment process also provides interested persons with the opportunity to challenge the factual assumptions on which the agency is proceeding, and to show in what respect such assumptions are in error.

(3) Publish a notice of final rulemaking at least thirty days before the effective date of the rule, which includes a statement of the basis and purpose of the rule and which responds to all substantive comments received. The APA makes an exception from the requirement for publication of the final rule thirty days before its effective date if the rule makes an exemption or relieves a restriction, or if the agency makes and publishes a finding that an earlier effective date is required "for good cause."

Rulemaking proceedings are usually started by an agency at its own initiative. However, the APA provides that each agency of the U.S. Government shall afford interested persons the right to petition for 
the issuance, amendment, or repeal of a rule. According to law, agencies must respond to the request. If the request has merit, work will commence on developing a proposed rule. In some cases, Congress (by statute) directs an agency to begin a rulemaking proceeding.

The APA also contains provisions for advance notice of proposed rulemaking. This allow agencies to seek general comments on issues prior to developing the specific regulatory proposal.

\section{OTHER U.S. STATUTORY AND LEGAL OBLIGATIONS IN THE CERTIFICATION AREA}

In addition to its openness and transparency obligations under the APA Act, the U.S. Government has other domestic and international obligations which affect the conformity assessment area. The U.S. Government is a signatory to a number of international trade agreements which affect conformity assessment, including

certification. For example, the U.S. Government was a signatory to the Agreement on Technical Barriers to Trade (also known as the "Standards Code") under the General Agreement on Tariffs and Trade (GATT), one of the first international agreements related to trade that recognized the importance of standards and certification systems for "improving efficiency of production and facilitating the conduct of international trade." The U.S. Trade Agreements Act of 1979 implemented the Standards Code in the United States. Title IV of the Act specifies obligations for the federal government, including responsibilities bearing on certification. Each federal agency must ensure that foreign products are treated in the same manner as domestic goods. Moreover, the federal government is to take reasonable measures to promote similar practices by state governments and the private sector.

December 15, 1993 saw a successful conclusion of the Uruguay Round of trade negotiations. In April 1994, the United States signed the Uruguay Round Agreements. These Agreements included a revision of the Agreement on Technical Barriers to Trade (the TBT Agreement). The Uruguay Round also created a new institution as a successor to the General Agreement on Tariffs and Trade (GATT), the World Trade Organization (WTO) .

The new TBT Agreement sought to ensure that technical regulations and standards, as well as testing and certification procedures, do not create unnecessary obstacles to trade. However, it recognized that countries have the right to establish protection at levels they consider appropriate (for example for human, animal or plant life or health or the environment), and should not be prevented from taking measures necessary to ensure that those levels of protection are met. 
The new agreement encourages countries to use international standards whenever appropriate, but does not require them to change their prescribed levels of protection as a result of standardization. The revised agreement also covers processing and production methods related to the characteristics of the product itself. The coverage of conformity assessment procedures was enlarged and the disciplines made more precise. Provisions applying to subnational government and non-government bodies were elaborated in more detail than in the prior TBT agreement.

In addition to its obligations under the new TBT Agreement, the U.S. Government has related conformity assessment obligations under the North American Free Trade Agreement (NAFTA). The U.S. Government actively participates in a number of regional efforts, designed to harmonize conformity assessment procedures and requirements and to promote the mutual recognition and acceptance of conformity assessment results.

The U.S. Government also has domestic requirements placed on it with respect to the conduct of conformity assessment activities.

Recently, Section 12, "Standards Conformity," of the National Technology Transfer and Advancement Act of 1995 was passed with "the goal of eliminating unnecessary duplication and complexity in the development and promulgation of conformity assessment requirements and measures." NIST was given responsibility for coordinating "Federal, state, and local technical standards activities and conformity assessment activities, with private sector technical standards activities and conformity assessment activities." The objective of section 12 is to encourage federal agencies to make greater use of and place increased reliance on private sector standards and conformity assessment activities and programs.

\section{CONCLUSION}

The United States has an extensive and sometimes complex system for ensuring the conformity of products sold in the U.S. marketplace to both mandatory and voluntary standards and requirements. Like the U.S. standards system, the U.S. certification system has evolved in a decentralized manner. It is based largely on declarations of conformity by manufacturers and suppliers of products sold in the U.S. marketplace, as well as on industry self-regulation. Many U.S. private sector organizations, as well as federal, state and local government agencies are involved in certification for a variety of reasons. The assurance of product conformity can involve one or more levels of government and increasingly involves reliance on private sector programs and activities. As both federal and state budgets shrink, greater emphasis is likely to be placed by government agencies 
at all levels on the use of and cooperation with certification programs available within the private sector. Despite its complexity, however, the U.S. certification system remains one of the most effective, open, and transparent systems in the world. 
